\title{
Changes in English language policy in Kim Jong-un's North Korea: A prelude to reconciliation? - CORRIGENDUM
}

\author{
HYEON-SEOK KANG
}

https://doi.org/10.1017/S0266078419000191, Published online by Cambridge University Press, 25 June 2019

The following citation in Kang (2019) is corrected to reflect the author's preferred spelling and the preferred translation of the title: Jung, C. K. 2017. '2013 English National Curriculum \& English textbooks in North Korea.' The Proceedings of the 2017 Conference of Korean Association of Teachers of English. Seoul: Korea Association of Teachers of English, pp. 115-119.

\section{Reference}

Kang, H.-S. 2019. 'Changes in English language policy in Kim Jong-un's North Korea: A prelude to reconciliation?' English Today. First View, 1-7. doi: 10.1017/ S0266078419000191. 